Journal of English Language Teaching and Applied Linguistics

ISSN: 2707-756X

DOI: $10.32996 /$ jeltal

Journal Homepage: www.al-kindipublisher.com/index.php/jeltal

JELTAL

\title{
Contrastive Analysis of Consonants in English and Vietnamese
}

\author{
Nguyen Thanh Huyen 8 (iD) \\ Foreign Languages Faculty, HCMC University of Food Industry, Vietnam. \\ $\triangle$ Corresponding Author: Nguyen Thanh Huyen, E-mail: huyennthanh@hufi.edu.vn
}

\section{ARTICLE INFORMATION \\ Received: May 04, 2021 \\ Accepted: June 06, 2021 \\ Volume: 3 \\ Issue: 6 \\ DOI: $10.32996 /$ jeltal.2021.3.6.8}

\section{KEYWORDS}

English consonants, Vietnamese consonants, contrastive analysis, differences, L2.

\section{ABSTRACT}

Language is an intensely indispensable tool. It has tremendous functions in communication. One is communicating and conveying messages, thoughts and ideas, feelings, insights, and mental treasures and values of a communicative society. Also, it enhances and strengthens fellowships, companionships, relationships and economic and cultural cooperation. However, language is very indistinct, unclear and confusing. This contrastive linguistics analysis will compare the consonants between English and Vietnamese. Thus, the author synthesizes stored information from various sources to compare differences in consonants between English and Vietnamese in comparative points. Then, some implications and discussion would be drawn for teaching English pronunciation, aiming at helping English learners pronounce like native speakers. The findings show that there are significant differences between English and Vietnamese consonants. This paper is intended to help teachers and English learners review English and Vietnamese consonants to minimize mistakes in their pronunciation, accommodating learners to build their confidence to communicate in L2.

\section{Introduction}

It is very important to explain how consonants are pronounced and how they are different from the others in English and Vietnamese. Why is it essential to know about the information background of the analysis? The same question arises in relation to grammar; at lower levels of study, one is concerned with laying out how to form grammatical sentences; however, people who plan to work with the language at a higher level as teachers or researchers require a more profound understanding provided by grammatical theory and related areas of linguistics. And so does the pronunciation. Accurate pronunciation is a solid foundation for those who learn foreign languages, as mentioned above. Nevertheless, my target readers are not advanced teachers or researchers. I conduct it in the form of a short research paper. This paper is about consonants in English and Vietnamese. Consonants filed is only a small part in phonetics and phonology subject. Peter Roach (2000) says that the disposition of phonetics and phonology will be interpreted as the course progresses.

In many languages, we can pinpoint a modest number of frequently used sounds - consonants and vowels like the consonants which are used at the beginning of the words "bet" and "pet" in English or "cây", "đây" in Vietnamese. What's more, due to the notoriously confusing nature between English pronunciation and Vietnamese pronunciation, especially in consonants, it is particularly pivotal to learn to think about one. Therefore, consonants play a vital part in the pronunciation learning process, as Benjawan Becker states that since it is one of the most important components in determining a syllable's tone, you must know the consonant class to pronounce what you have read correctly. Let us talk about how to categorize consonants. In contrastive analysis, we need to decide the base of phonetics description. The typical characteristic of consonants is when pronounced. They are formed by the breath airflow being stuck: manner of articulation and articulation, which will be given in details below. Because learning a foreign language is an essential factor in education, such an integral world and correct and proper pronunciation will contribute to effective communication. This paper aims to clarify characteristics in consonants between English and Vietnamese; from then, contrasts are concluded. Besides, at the end of the research paper, there are implications in teaching language and discussions. Also, this research paper will provide basic information that is helpful for those who practice taking in the significance of pronouncing consonants accurately.

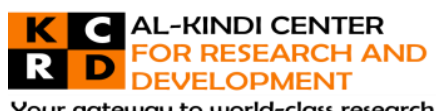

Your gateway to world-class research

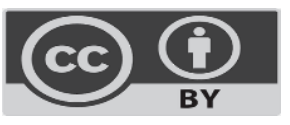

Published by Al-Kindi Center for Research and Development, United Kingdom. Copyright (c) the author(s). This open access article is distributed under a Creative Commons Attribution (CC-BY) 4.0 license 


\section{Literature Review}

Pronouncing and distinguishing consonants are not simple tasks, so to improve it, we need to know about consonants and how they work first.

So what is a consonant? According to the Oxford Advanced Learner's Dictionary, a consonant is a speech sound made entirely or partially stopping the flow of air being breathed throughout the mouth. Thiem (2004) state that consonants are sounds created by meeting with an obstacle in the articulator and these sounds are not easy to hear, not soft and do not have a fixed frequency. For examples, the letters " $\mathrm{p}$ " and " $\mathrm{b}$ " are formed by pressing the lips together; " $\mathrm{t}$ " and " $\mathrm{d}$ " are formed by pressing the tongue blade against the alveolar ridge; and " $\mathrm{f}, \mathrm{s}$ " are formed when air escapes through a small passage and forms a hissing sound; or with " $m, n$ " are when air escapes through the nose (Roach, 1983, p.49, 58). We can see that no matter what the definitions are, they are pretty similar to each other and based on the same phonetics theory but just expressed in different ways.

How are consonants constructed? Let us take a look at the articulators below.

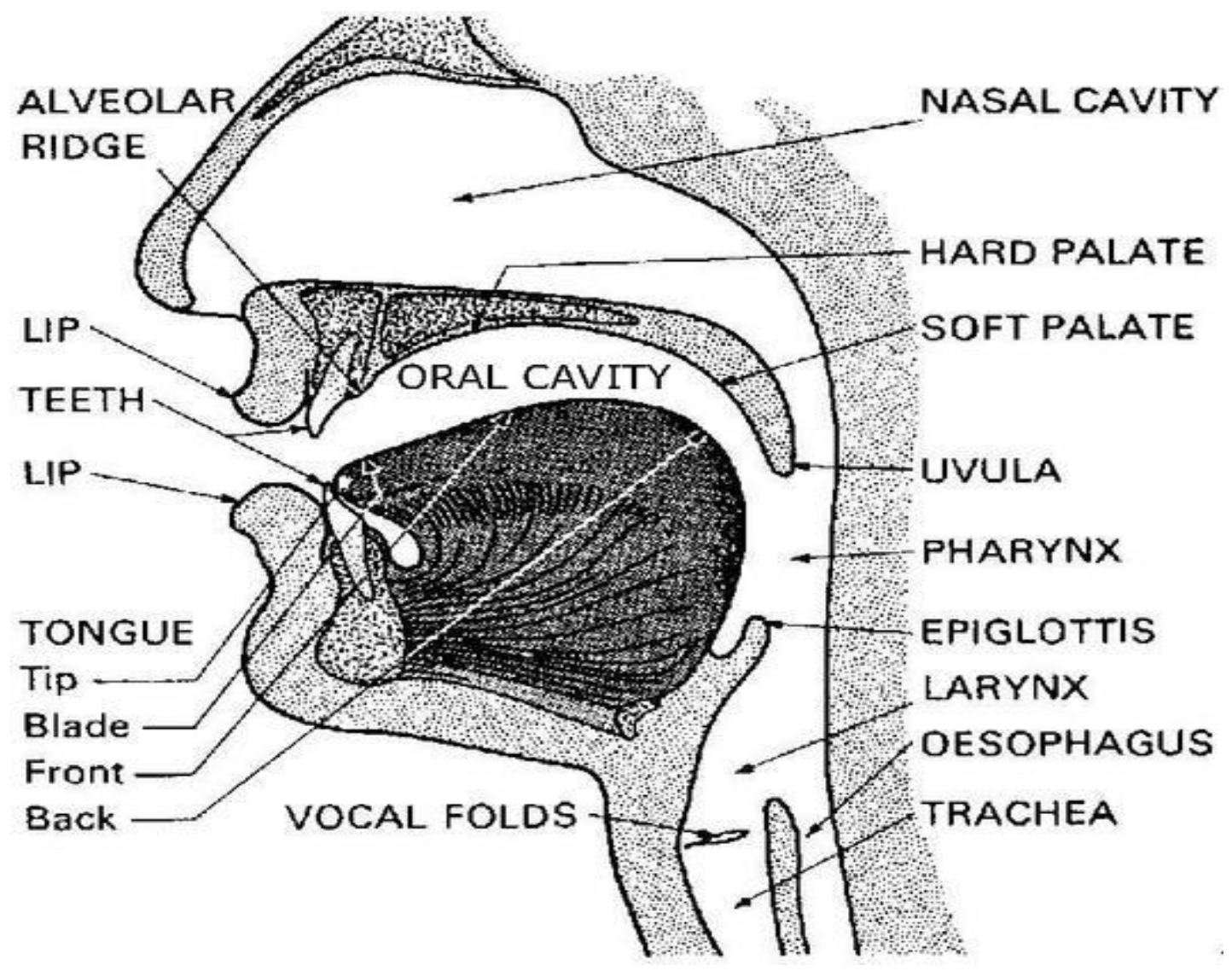

(Figure 1: The articulatory system)

The articulator is a system including what is involved in the actual motions of various parts of the vocal tract, which ends at the mouth and nostrils during speech. Consequently, to classify consonants, we need to base on two different bases: manners of articulation and places of articulation.

In terms of the manners of articulation, we have plosive $(p, b)$, fricative $(h, v)$, nasal $(\mathrm{m}, \mathrm{n}, \mathrm{ng})$, lateral $(\mathrm{I})$ and approximant $(\mathrm{r})$. Besides these consonants, we also have aspirated other ones like " $c$ " in English and "th" in Vietnamese. Manners of articulation will illustrate how lips, mouth, tongue, teeth, larynx get constructed to make a sound. Moreover, they are methods of modifying moving air blocked when producing the consonants (Thiem, 2004, p.97)

In terms of the places of articulation, there are different types, such as bilabial $(p, b)$, labio-dental $(f, v)$, dental $(\theta)$, alveolar $(t, d, n$, I), palato- alveolar (s, ch), velar ( $k, g, n g)$ and glottal (h) in two languages. Speech organs like lips, teeth, alveolar ridge, tongue tip, tongue blade, or back of the tongue, hard palate, soft palate, glottis, pharynx are features to make the sounds.

As we can see, the basis to describe consonants mentioned above depend on the manner of articulation and place of articulation. Here are traditional descriptive ways. These standards are very different from the vowels. Modern linguistics 
discussed the description of the sounds depending on the machine and convalesced the differences between these two criteria that are applied for the consonants and the vowels. Therefore, to understand more about the consonants of each language, we will be going to learn in details.

\subsection{Consonants in English}

According to Peter Roach (2000), English has 24 consonants. they are /p/, /b/, /m/, /f/, /v/, /t/, /d/, /ð/, /t/, /d/, /n/, /l/, /J/, /ty/, $/ \mathrm{d} /, \mathrm{l} / \mathrm{k} / \mathrm{,} / \mathrm{g} / \mathrm{,} / \mathrm{r} / \mathrm{,} / \mathrm{h} / \mathrm{,} / \mathrm{w} /, / \mathrm{j} /, / \theta /, / 3 /, / \mathrm{h} /$. These consonants are categorized depending on two bases above: manners of articulation and place of articulation. Let's take a glance at this table.

THE TABLE OF ENGLISH CONSONANTS

\begin{tabular}{|c|c|c|c|c|c|c|c|c|}
\hline$V^{v \mid t r i}$ & $\begin{array}{l}\text { Môi-môi } \\
\text { (bilabia) }\end{array}$ & $\begin{array}{c}\text { Môi-rằng } \\
\text { (labiodental) }\end{array}$ & $\begin{array}{c}\text { Răng } \\
\text { (dental) }\end{array}$ & $\begin{array}{c}\text { Loi } \\
\text { Alveolar) }\end{array}$ & $\begin{array}{c}\text { Ngac-loi } \\
\text { (palatoalveolar) }\end{array}$ & $\begin{array}{c}\text { Ngac } \\
\text { (palatal) }\end{array}$ & $\begin{array}{l}\text { Mac } \\
\text { (Velar) }\end{array}$ & $\begin{array}{c}\text { Hong } \\
\text { (glottal) }\end{array}$ \\
\hline Tấc (plosive) & $\mathrm{p}, \mathrm{b}$ & & & $t, d$ & & & $k, g$ & \\
\hline Xát (fricative) & & & $\theta, 0$ & $\mathrm{~s}, \mathrm{Z}$ & $\int, 3$ & & & h \\
\hline $\begin{array}{l}\text { Tắc-xát } \\
\text { (affricative) }\end{array}$ & & & & & $t, d z$ & & & \\
\hline Mũi (nasal) & $\mathrm{m}$ & & & $\mathrm{n}$ & & & I) & \\
\hline Bên (lateral) & & & & 1 & & & & \\
\hline $\begin{array}{l}\text { Gần đúng } \\
\text { (approxima } \\
\text { nt) }\end{array}$ & w & & & & $\mathrm{r}$ & $\mathrm{J}$ & & \\
\hline
\end{tabular}

(Figure 2: Manner of articulation \& Place of articulation) 
below is a table with examples about each consonant in English and corresponding words. It will help us have a more specific overview of the 24 consonants.

\begin{tabular}{|c|c|c|c|c|c|c|c|}
\hline $\mathrm{P}$ & b & $\mathbf{t}$ & d & $f$ & $\mathbf{V}$ & $\theta$ & ठ \\
\hline $\begin{array}{l}\text { /pin/ } \\
\text { pin }\end{array}$ & $\begin{array}{c}\text { /bæd/ } \\
\text { bad }\end{array}$ & $\begin{array}{c}/ \operatorname{tin} / \\
\operatorname{tin}\end{array}$ & $\begin{array}{l}\text { /dog/ } \\
\text { dog }\end{array}$ & $\begin{array}{l}\text { /faiv/ } \\
\text { five }\end{array}$ & $\begin{array}{l}\text { /væn/ } \\
\text { van }\end{array}$ & $\begin{array}{l}/ \Theta \text { ın/ } \\
\text { thin }\end{array}$ & 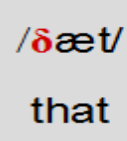 \\
\hline $\mathbf{m}$ & $\mathbf{n}$ & $\eta$ & h & t1 & ds & $\mathbf{k}$ & $g$ \\
\hline $\begin{array}{l}\text { /mæn/ } \\
\text { man }\end{array}$ & $\begin{array}{l}\text { /nəuz/ } \\
\text { nose }\end{array}$ & $\begin{array}{l}\text { /Oın/ } \\
\text { thing }\end{array}$ & $\begin{array}{c}\text { /ha:f/ } \\
\text { half }\end{array}$ & $\begin{array}{c}\text { /tø:t// } \\
\text { church }\end{array}$ & $\begin{array}{c}\text { /dzæm/ } \\
\text { jam }\end{array}$ & $\begin{array}{l}\text { /kaind/ } \\
\text { kind }\end{array}$ & $\begin{array}{l}\text { /g^n/ } \\
\text { gun }\end{array}$ \\
\hline $\mathbf{S}$ & Z & & & & $\boldsymbol{r}$ & $\mathbf{W}$ & \\
\hline $\begin{array}{l}\text { /sev } \\
\text { say }\end{array}$ & $\begin{array}{l}\text { /zu:/ } \\
\text { zoo }\end{array}$ & $\begin{array}{l}\text { //ip/ } \\
\text { ship }\end{array}$ & $\begin{array}{l}\text { /mezə/ } \\
\text { measure }\end{array}$ & $\begin{array}{l}\text { /leg/ } \\
\text { leg }\end{array}$ & $\begin{array}{l}\text { /r^n/ } \\
\text { run }\end{array}$ & $\begin{array}{l}\text { /wə:k/ } \\
\text { work }\end{array}$ & $\begin{array}{l}\text { /jes/ } \\
\text { yes }\end{array}$ \\
\hline
\end{tabular}

(Figure 3: English consonants)

\subsection{Consonants in Vietnamese}

Being different from English consonants, according to Thuat (1980), there are a total of 30 consonants in Vietnamese, including 22 initials consonants (standing at the beginning of the syllable): /b/, /m/, /f/, /v/, /t/, /t'/, /d/, /n/, /z/, / / $/$ /, /s/, /s /, /c/, /t,/, /n/, /l/, $/ \mathrm{k} /, / \mathrm{X} /, / \mathrm{y} /, / \mathrm{\gamma} /, \mathrm{h} /, \mathrm{l} / \mathrm{f}$; and 8 final consonants: 6 consonants : /p/, /t/, /k/, /m/, /n/, /y/ and 2 semi-consonants (also called

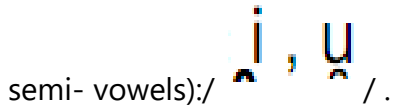

Here is the table of 22 initial consonants in Vietnamese.

\begin{tabular}{|c|c|c|c|c|c|c|c|c|c|c|c|c|}
\hline & & 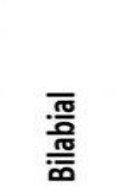 & 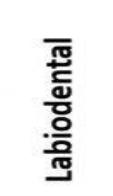 & $\begin{array}{l}\overline{\text { Tू }} \\
\text { هั }\end{array}$ & $\frac{\frac{2}{c}}{\mathrm{c}}$ & & 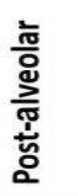 & 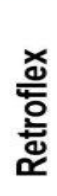 & 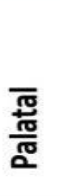 & & $\bar{z}$ & $\begin{array}{l}\text { 焉 } \\
\text { 은 }\end{array}$ \\
\hline & Nasal & $\mathrm{m}$ & & & & $\mathrm{n}$ & & & $\mathrm{n}$ & & り & \\
\hline \multirow{3}{*}{ 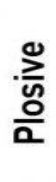 } & \multirow{3}{*}{$\begin{array}{r}\text { plain } \\
\text { aspirated } \\
\text { glottalized }\end{array}$} & $p$ & & $\mathrm{t}$ & & d & & & C & & $\mathrm{g}$ & \\
\hline & & & & th & & & & & & & & \\
\hline & & 6 & & & & & d & & & & & \\
\hline & Fricative & & f $v$ & & & z & & & & & $\gamma$ & $\mathrm{h}$ \\
\hline & pproximate & & & & & $\lambda$ & & & j & & w & \\
\hline & Lateral & & & & & I & & & & & & \\
\hline
\end{tabular}

(Figure 4) 
Below is the equivalent table of initial Vietnamese consonants and writings:

\begin{tabular}{|c|c|c|c|c|c|c|c|}
\hline Stt & Âm & Con chữ & Ví dụ & Stt & Âm & Con chũ & Ví dụ \\
\hline 01 & $b$ & $\mathrm{~b}$ & ba, bàn & 12 & ţ & $\operatorname{tr}$ & trâu trắng \\
\hline 02 & $\mathrm{~m}$ & $\mathrm{~m}$ & mạ, mang & 13 & Ş & $\mathrm{s}$ & sâu sắc \\
\hline 03 & $f$ & ph & phao, pha & 14 & $z$ & $r$ & ráo riết \\
\hline 04 & v & v & vào, việt & 15 & C & $\mathrm{ch}$ & chào chú \\
\hline 05 & $\mathrm{t}^{\prime}$ & th & thấy, tha & 16 & $n$ & $\mathrm{nh}$ & nhả nho \\
\hline 06 & $\mathrm{t}$ & $\mathrm{t}$ & tay, ta & 17 & $\mathrm{k}$ & $c, k, q$ & co, quả, kẹo \\
\hline 07 & $d$ & $d$ & đi, dứng & 18 & $\eta$ & ng, ngh & ngày, nghèo \\
\hline 08 & $\mathrm{n}$ & $\mathrm{n}$ & nao, núng & 19 & $x$ & $\mathrm{kh}$ & khó khăn \\
\hline 09 & $\mathrm{~s}$ & $\mathrm{x}$ & xanh, xây & 20 & $\gamma$ & g, gh & gà, ghẻ \\
\hline 10 & $z$ & d, gi & dày, gian & 21 & $?$ & khuyết & \\
\hline 11 & I & I & lo, lắng & 22 & $\mathrm{~h}$ & $\mathrm{~h}$ & hay, ho \\
\hline
\end{tabular}

(Figure 5, Thiem, 2004)

As mentioned previously, we have 8 ending consonants in Vietnamese. In order to differentiate ending consonants, it depends on the criteria in this table:

\begin{tabular}{|c|c|c|c|c|}
\hline \multicolumn{3}{|c|}{ Định vị môi (lips) } & \multicolumn{2}{|c|}{ Đầu lưỡi (tongue) } \\
\hline \multicolumn{3}{|l|}{ Phương thức (Manners) } & $\begin{array}{c}\text { Đầu lưỡi (tongue } \\
\text { tip) }\end{array}$ & Mặt lưỡi (middle) \\
\hline \multicolumn{2}{|l|}{ noise consonant } & $\mathrm{p}$ & $\mathrm{t}$ & k \\
\hline \multirow[t]{2}{*}{ sonant } & không mũi (non-nasal) & $\mathrm{m}$ & $\mathrm{n}$ & $\eta$ \\
\hline & Mũi (nasal) & $\underline{u}$ & \multicolumn{2}{|c|}{ } \\
\hline
\end{tabular}

(Figure 6)

In Vietnamese, syllables contrast by different ending ways. The syllable ends by lasting and remaining, generally, punctuations of syllables like má, cho, đi. Other syllables finish by changing punctuations: tai, đau, mắt, chân, khóc, suốt. About semi-consonants, /i/ - (tai), /u/- (đau), or consonants /n/- (chân), /k/- (khóc), /t/- (suốt). 
And below is the table of corresponding Vietnamese ending consonants and writings:

\begin{tabular}{|c|c|c|c|c|}
\hline Stt & Âm & Con chữ & Ghi chú & Ví dụ \\
\hline 01 & $p$ & $P$ & Mọi trường hợp & Tạp, lập, úp, mép \\
\hline 02 & $\mathrm{t}$ & $t^{\prime}$ & Mọi trường hợp & Át, lét, nét, mát \\
\hline \multirow{2}{*}{03} & \multirow{2}{*}{ k } & $\mathrm{ch}$ & Sau nguyên âm bỗng i, ẽ, e & Dịch, sách, lệch, đích \\
\hline & & c & Trong các trường hợp khác & Lấc cấc, mốc, thóc \\
\hline 04 & $\mathrm{~m}$ & $\mathrm{~m}$ & Mọi trường hợp & Nam, àm, nhàm, tám \\
\hline 05 & $\mathrm{n}$ & $\mathrm{n}$ & Mọi trường hợp & Nhân dân, tán, hạn \\
\hline \multirow[t]{2}{*}{06} & $n$ & $\mathrm{nh}$ & Sau âm bổng i, ẽ, e & Tinh, tránh, sinh, bệnh \\
\hline & $\eta$ & ng & Trong các trường hợp khác & Trông, mong, đứng, đường \\
\hline \multirow{2}{*}{07} & \multirow{2}{*}{ u } & 0 & Sau nguyên âm đơn dài & Tao, lao, vào, bao \\
\hline & & u & Trong các trường hợp khác & Đau, đầu, tiu, nghiu \\
\hline 08 & i & $y$ & Sau nguyên âm ngắn & Lấy, lây, bấy, nay \\
\hline
\end{tabular}

(Figure 7)

\section{A contrastive analysis of consonants between English and Vietnamese}

As mentioned above, in each separated part of consonants, English has 24 consonants (Roach, 1983) and we will rely on three criteria to sort them out: voicing, manner of articulation and place of articulation. Furthermore, in English, consonants can stand in an initial position, medial position and final position. Whereas Vietnamese has 30 consonants: 22 initial consonants and 8 ending consonants (Thuat, 1980); in ending consonants, 6 consonants ( $p, t, k, m, n, \eta)$ and 2 semi- consonants (or semi-vowels): i , un . And in semi- consonants, more specifically, there can be no change in the final phoneme's timbre; as a result, it becomes zero ending consonant, such as má, lá, chơ, tho. Or besides, it can change in the final phoneme's timbre (closing), so we will have ending consonants, mai, tai, đau, thau, for instance.

When compare two tables of consonants in English and Vietnamese according to bases of articulation, we will realize that the table of Vietnamese consonants is more detailed and focused. This is demonstrated in terms of the manner of articulation. The phonologist points out clearly 2 general manners: plosive and fricative, and then details each manner into obstruent and sonant, and after that goes on categorizing into aspirated, unaspirated, voiced, voiceless. From these different ways to distinguish and classify consonants in English and Vietnamese, we can have differences when contrasting consonants. Regarding Plosive in Vietnamese, we have aspirated $\mathbf{t}^{\prime}$; obstruent plosive, unaspirated, voiceless, we have $\mathbf{t}, \mathbf{t}, \mathbf{c}$, $\mathbf{k}$; obstruent plosive, unaspirated, voiced b,d; plosive, sonant, nasal $\mathbf{m}, \mathbf{n}, \mathbf{n}, \mathbf{n}$. In contrast, plosive consonants in English combine both sonant plosive and affricative. In plosive, there are $\mathbf{p}, \mathbf{b}, \mathbf{t}, \mathbf{d}, \mathbf{g}, \mathbf{k}, \mathbf{m}, \mathbf{n}$; affricative $\mathbf{t}, \mathbf{d} \mathbf{3}$. In these consonants, we have $\boldsymbol{g}$, which belongs to English plosive, but $\mathbf{\gamma}$ belongs to Vietnamese fricative.

Syllables in Vietnamese differ in their endings. Some syllables, such as má, cho, đi, retain and preserve the timbre of the principle phoneme, the so-called zero consonant, Furthermore, due to the closure of the articulators, some syllables change timbre at the last phoneme, resulting in two types: semi- consonants / / (tai), / / (đau) and consonants: /n/ (chân), /k/ (khóc), /t/ (suốt). 
However, in Peter Roach's view, consonants in English can be at the initial, medial and final position. What's more, all consonants, apart from /h/ (glottal), are differentiated fortis (strong) from lenis (weak). This differentiation depends on pronouncing the syllables that vowel stands in front of the ending sound of those syllables are short vowels, long vowels or diphthongs:

- Long vowels are weak final consonants (lenis), for examples, rye /rai/, hers / h3:z/, rise /raiz/, heard /h3:d/.

- Short vowels are strong final consonants (fortis), such as hearse /h3:s/, rice /rais/, right /rait/, hurt /h3:t/ . Similarly, the final consonants of the syllables like $\mathbf{p}, \mathbf{t}, \mathbf{k}$ in belt /belt/, bump /b^mp/, bank /bæjk/ are strong consonants and other consonants $\mathbf{l}$, $\mathbf{m}, \mathbf{n}$ in English are also the same.

Another comparison I would like to make is that from the charts of consonants in English and Vietnamese I attached previously, we can find that the Vietnamese chart is detailed. In addition, there are more categorizing criteria for the manner of articulation and less categorizing place of articulation in Vietnamese.

In Vietnamese consonants, phonologists normally pay more attention to tongue position (đầu lưỡi, mặt lưỡi, gốc lưỡi, lưỡi bẹt, quặt lươii) like Flat, Retroflex, Dorsal; by contrast, English authors describe more details about other articulators, such as Palatal Alveolar, Alveolar, Dental (môi- răng, môi, răng, ngạc- Iợi, lợi, ngạc, mạc).

Similarly, let us make a contrast between English and Vietnamese Fricatives. In Vietnamese, in terms of the manner of articulation for Fricatives, we have Fricative, Obstruent, Voiceless $\boldsymbol{f}, \boldsymbol{s}, \boldsymbol{s}, \boldsymbol{x}, \boldsymbol{h}$; Fricative, Obstruent, Voiced like $\boldsymbol{v}, \boldsymbol{z}, \boldsymbol{z}, \boldsymbol{\gamma}$; Fricative, Sonant, Lateral: $\boldsymbol{l}$. Contrastively, in English, the same consonants are fricative, sonant, lateral, alveolar: $\boldsymbol{l}$; fricative, glottal: $\boldsymbol{h}$. The different

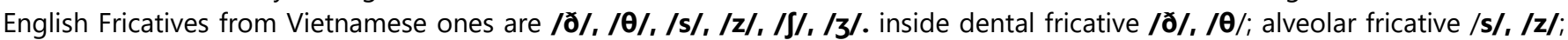
palato- alveolar fricative $/ \mathrm{S} /, \mathrm{l} / \mathrm{/}$

Moreover, English also has consonants that Vietnamese does not have. They are approximant (âm gần đúng) being consisted of bilabial: /w/; palato - alveolar approximant: / $/ \mathbf{f}$; and palatal approximant: /j/. We need to notice that while the consonants $\boldsymbol{k}, \boldsymbol{g}$ in English are velar plosive, $\boldsymbol{k}$ is tongue plosive and $\boldsymbol{\gamma}$ is tongue fricative in Vietnamese. Additionally, there is a consonant that exists in Vietnamese but does not have in English, $\boldsymbol{n}$. Besides that, on account of these differences, some Vietnamese learners could have difficulty in pronouncing these consonants, like $/ \mathbf{t} /, \mathbf{d} \mathbf{3} /$ in English because people have the local accent, especially people in the North of Viet Nam.

Those are some comparisons that I have made about the discrepancies between Vietnamese and English consonants.

\section{Discussion and implications for teaching languages.}

First of all, in my opinion, many Vietnamese students have limited capabilities of speaking English and pronouncing them accurately, which is because they do not spend adequate time teaching and learning to speak in class; pronunciation in particular. In addition, in Vietnam, almost all the English examinations or assessments in our state-funded schools only emphasize writing skills with vocabulary and grammar. Our national education system does not take the importance of oral tests seriously; as a consequence, when teaching English, Vietnamese teachers just also concentrate on teaching the grammar points and vocabularies so that their students can meet the requirements of the curriculums and get high scores in the examinations. This way of teaching is not wrong in some specific points; however, in terms of long-lasting effects, Vietnamese students cannot get used to pronouncing English correctly and naturally in communications when they go to work, in particular. If we teach them the vocabularies or grammars but not pronunciation, they will not apply and practice what we teach them in their real lives. In this case, students are "industrially raised chickens" alike. Consequently, to help improve this situation, teachers should integrate teaching pronunciation into each lesson taught in class, requiring students to read aloud the words and correct them immediately if they make the mistakes.

Secondly, it can become a bad habit if students misread the words or the sounds continually day by day. When a student is not taught to pronounce a word appropriately, he or she will remember this wrong pronunciation and repeat this mistake for a very long time. If we do not correct their wrong pronunciation, our students will mispronounce for after ever and there will be less likely that these learners can change their habit. Of course, it leads to severe consequences and has horrible effects on their lives later on.

Thirdly, we are English teachers, so we should teach English, not Vietnamese, pay more attention to teaching speaking and pronunciation, I mean. Therefore, I suppose that we had better use English regularly in class so that our students can get accustomed to listening and reacting to speak English naturally and fluently. In addition, make sure that teaching for students read the sounds correctly means that teachers need to be careful to check the transcript in the dictionary when feeling uncertain about the pronunciation. Remember that if we mispronounce the words, our students will mimic exactly and they will mispronounce them, too. 
I would like to discuss here that we should apply technology into teaching English, especially speaking and listening, and add spoken tests as an official assessment way students' learning progress. For example, we can use recordings, videos, tapes from the internet with native speakers' voice to teach so that our students can familiarize the voice, the intonation and the stress. Alternatively, instead of using traditional tests only like grammar tests or writing tests, we can use spoken tests and other tests to assess students and help them use language flexibly.

Last but not least, as I have stated above, there are some similar consonants between Vietnamese and English; or there are some sounds just existing in one language but not the other. We must help our students compare and differentiate similar sounds; and find easy methods to support them in remembering and pronouncing hard sounds in a second language, generally.

\section{Conclusion}

Consonant is one of the important aspects of phonetics that students who learn languages need to practice regularly. Nevertheless, in high schools, due to Viet Nam's educational features, it does not let teachers of English pay much attention to teaching pronunciation and phonetics. They are often required to focus mainly on grammar points and vocabularies, which students need to practice to deal with the assessments and examinations. From my points of view, teachers, even educationalists in Viet Nam normally underestimate the importance of teaching English pronunciation. Most high school students cannot pronounce English properly. As a result, they feel awkward and embarrassed when communicating with native speakers because they fear making mistakes and misunderstanding. Being a teacher of English in the future, I realize that we have to consider all areas of English such as pronunciation, intonation, vocabulary, grammar, and stress seriously. Objectively, I acknowledge the necessity of teaching pronunciation, as pointed at the beginning of this paper research. Therefore, I think it is essential to catch students' attention to the importance of pronouncing English properly and accurately right from the first lessons of beginners; and orient them toward practicing reacting to speak English every day. To fulfill this aim, teachers should master English and Vietnamese phonetics to take them as models to assist students with intelligible and easy-to-recollect ways. One more thing, I myself currently is a learner of English, too. However, I did not have many opportunities to practice speaking English when I was in high school. Therefore, I still sometimes encounter few difficulties in pronouncing some words. That reason prompts me to choose this topic. I would like to learn more about the variations between English and Vietnamese consonants to pronounce them and teach them later accurately.

Furthermore, I hope that I, myself, and my pupils will confidently and successfully communicate in English with foreigners because the ultimate goal of speaking is to communicate in real life. I hope that my work helps other scholars understand more about the system of Vietnamese consonants and some contrastive analyses. From this one, you can realize the significant role of teaching phonetics for the sake of pronunciation for the learners right away at the beginning level, helping them avoid confusions among some consonants (Miller \& Nicely, 1955).

Funding: This research received no external funding.

Conflicts of Interest: The author declares no conflict of interest. The funders had no role in the study's design, in the collection, analyses, or interpretation of data, in the writing of the manuscript, or in the decision to publish the results.

\section{References}

[1] April, M. (2002). An Introduction to English Phonology. Edinburgh: Edinburgh University Press.

[2] Articulatory Phonetics. (2015, May 25 ${ }^{\text {th }}$ ). Linguistics 201. http://pandora.cii.wwu.edu/vajda/ling201/test2materials/articulatory phonetics.htm

[3] Âm vị và các hệ thống âm vị tiếng Việt. (2006, August 24 ${ }^{\text {th }}$ ). NGONNGU.NET. http://ngonngu.net/index.php?p=64

[4] Miller, G. A., \& Nicely, P. E. (1955). An Analysis of Perceptual Confusions Among Some English Consonants. Journal of the Acoustical Society of America, 27(2), 338-352. https://doi.org/10.1121/1.1907526

[5] Norquist, R. (2019, July 26). DO YOU KNOW EVERYthing AbOUt CONSONANT SOUNDS AND LETTERS IN ENGLISH? THOUGHTCO. HTTP://GRAMMAR.ABOUT.COM/OD/C/G/CONSONATERM.HTM

[6] Ngoc, L., L. (2014). Đối chiếu phụ âm trong tiếng Việt và tiếng Anh. LuanVan.co. http://luanvan.co/luan-van/doi-chieu-phu-am-trong-tiengviet-va-tieng-anh-52243/

[7] Roach, P. (1983). English Phonetics and Phonology A practical course (Fourth edition). Cambridge: Cambridge University Press.

[8] Thiêm, L., Q. (2004). Nghiên Cứu Đối Chiếu Các Ngôn Ngũ. Hà Nội : Nhà xuất bản Đại học quốc gia Hà Nội.

[9] Thuật, D., T. (1980). Ngữ âm tiếng Việt. Hà Nội: Đại học và Trung học Chuyên nghiệp. 